\title{
Purification and Electrophoretic Behavior of Sugarcane Invertases
}

\author{
Alex G. Alexander ${ }^{1}$
}

\section{INTRODUCTION}

During the past 5 years much information has been gathered concerning the number and roles of invertases in sugarcane. Glasziou and coworkers have described an acid and a neutral invertase involved in sugar storage $(13,15) .^{2}$ The acid invertase was also correlated with elongation rates of immature internodes (16). Sacher and Glasziou found that naphthalene acetic acid and indoleacetic acid increased the enzyme's activity $(18,19)$. Glucose was claimed to have inhibited invertase, as did sugar derivatives and polyhydric alcohols (12).

In Puerto Rico invertases have been studied with regard to number and properties $(1,2)$, and to their behavior following variable treatment of growing cane $(3,5)$. Broad discrepancies of action have been found among different varieties $(4,6)$. Silicon has been shown to inhibit invertase when supplied as a nutrient supplement $(7,20)$.

Yet there remains a major problem of purifying the enzyme complex to a level which affords reliable analysis. This paper summarizes procedures of differential solubility, gel filtration, and paper electrophoresis which have proven satisfactory for resolution of the enzymes from inert protein and from one another.

\section{MATERIALS AND METHODS}

Enzyme preparations were made with lyophilized meristem tissue from the variety P.R. 980. Procedure was identical with that described earlier (1), with the exceptions that no sonic disintegration treatment was included, and all protein samples were dialyzed overnight against distilled water.

Invertase activity was ascertained by measuring the amount of reducing sugar formed during a standardized reaction. The digest was composed as follows: $1.0 \mathrm{ml}$. of $0.1-\mathrm{M}^{3}$ acetate buffer $(\mathrm{pH} 5.5) ; 1.0 \mathrm{ml}$. of 1-percent substrate solution; $0.25 \mathrm{ml}$. of additive solution, and $0.25 \mathrm{ml}$. of enzyme preparation. Reference digests received water in place of enzyme. The reaction proceeded for 1 hour and was then terminated with $1.0 \mathrm{ml}$. of dinitro reagent. Color was developed by the dinitrosalicylic acid technique

1 Associate Plant Physiologist, Agricultural Experiment Station, University of Puerto Rico, Río Piedras, P.R.

2 Italic numbers in parentheses refer to Literature Cited, pp. 44-5.

3 The letter M signifies "molar" herein. 
of Summer (21), and reducing sugar was estimated by reference to a standard curve representing 0.01 to $0.20 \mathrm{mg}$. of $d$-glucose. One activity unit was defined as the amount of enzyme catalyzing the formation of 0.1 $\mathrm{mg}$. of reducing sugar per hour. Protein content of the invertase preparations was determined colorimetrically by the method of Sutherland et al. (22) and enzyme action was computed in terms of specific activity (units/ milligrams of protein).

Filtration experiments were run with $2.5 \times 30$-cm. columns packed with G-200 Sephadex. ${ }^{4}$ Composed of highly cross-linked dextrans acting as a moleeular sieve, Sephadex has been used successfully here for the purification of phosphatase (8) and amylase (9). It is highly praised by other workers $(11,10,14)$. After soaking in water for several minutes the Sephadex was poured into columns where it formed a true gel. Enzyme samples of 3- or 4-ml. volume were absorbed on the columns and eluted with distilled water. One-centimeter fractions were collected until virtually all of the samples had been eluted.

After filtering the enzyme preparation through Sephadex, peak-activity fractions were concentrated by freeze-drying and examined electrophoretically. A Beckman Model R paper electrophoresis system was employed. Standard separations were run for 6 to 8 hours with $0.02-\mathrm{M}$ phosphate buffer ( $\mathrm{pH} 8.0$ ) and a constant-current supply of 2.5 ma. Paper strips were air-dried at the completion of a given run and then cut into 1-cm. sections. The sections were eluted with $1 \mathrm{ml}$. of distilled water. Enzyme assays were conducted as usual with the eluted protein.

\section{RESULTS AND DISCUSSION}

\section{DIFFERENTIAL SOLUBILITY AND DIALYSIS}

Sugarcane invertase is readily precipitated by ammonium sulfate in the range of 38- to 52-percent saturation (fig. 1). Maximum activity is obtained at about 46-percent saturation when sucrose or the trisaccharide raffinose is used as substrate. A secondary activity peak appears at 26 percent when either raffinose or melezitose is substrate, but this is not evident when sucrose is used.

Dialysis of the 38- to 52-percent fraction leads to severe inactivation of cane invertase (1). In the past we overcame this difficulty by adding traces of glucose or manganese to the dialyzed preparation. It is not clear, however, whether the enzyme thus activated represents the same catalyst available prior to dialysis. The possibility exists that a new protein-sugar activator complex is created. For this reason, and because, at this time, we were interested in the behavior of the invertase protein, no use was made of

${ }^{4}$ Farmacia of Fine Chemicals, Rochester, Minn. 
activators. The 38- to 52-percent fraction was applied directly to Sephadex columns following overnight dialysis against distilled water.

\section{GEL FILTRATION}

Invertase apparently regains some of its lost activity during passage through Sephadex. A single activity peak was obtained from fractions 18 to 22 (fig. 2). Had activators been used we would have expected three areas of activity on the basis of earlier filtration studies (17). Nevertheless, the single peak obtained here represents a marked revival of activity lost during the previous dialysis, and corresponds to the major activity area obtained even when activators are employed.

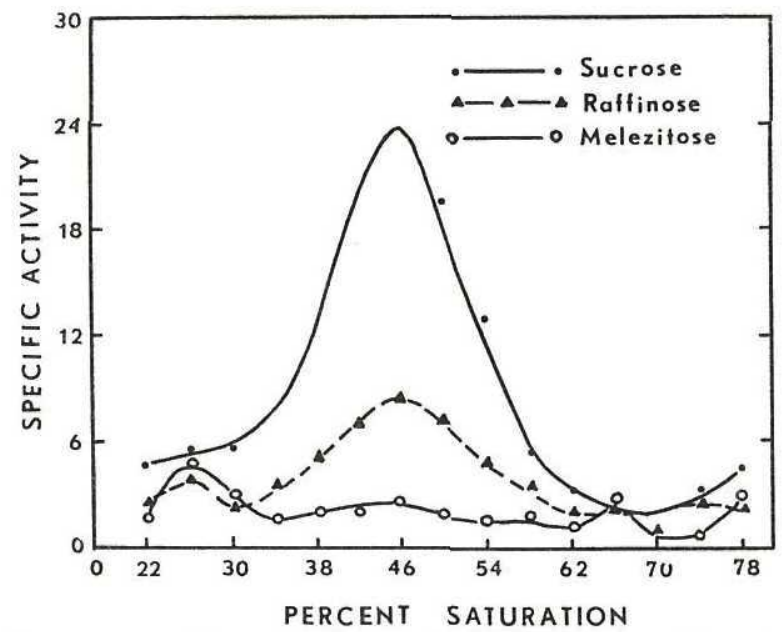

FIG. 1.- Invertase activity among protein increments precipitated by ammonium sulfate from extracts of sugarcane meristem.

Figure 2 illustrates that invertase was not clearly separated from the bulk of protein passing through the dextran gel. An important property of Sephadex, that of protein-enzyme resolution, was therefore not achieved with invertase. The specific-activity increases obtained might then be attributed to a removal of endogenous inhibitors. Such inhibitors are known to be present in meristem extracts, and apparently are retained by the enzyme during dialysis (17). In this respect sugarcane phosphatases have also been shown to lose inhibitors during filtration which could not be removed by dialysis (8).

\section{SEPARATION BY ELECTROPHORESIS}

Electrophoresis experiments accomplished both the separation of invertase from contaminant protein and resolution of two distinct invertase 


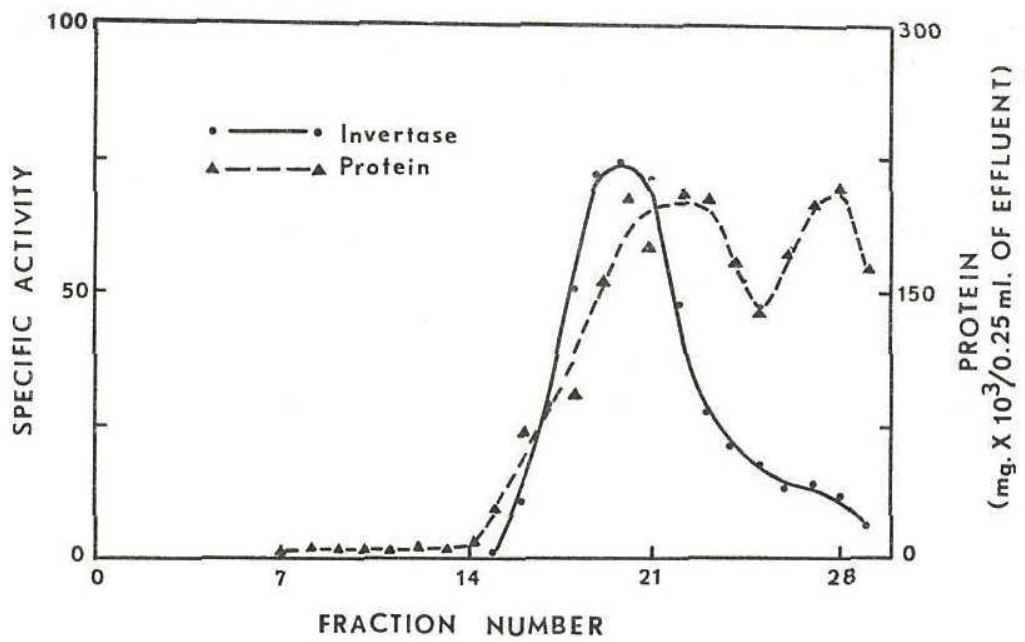

FrG. 2.-Invertase activity and protein content among effluents of sugarcane meristem preparations passed through Sephadex. The standard invertase reaction was run without activators.

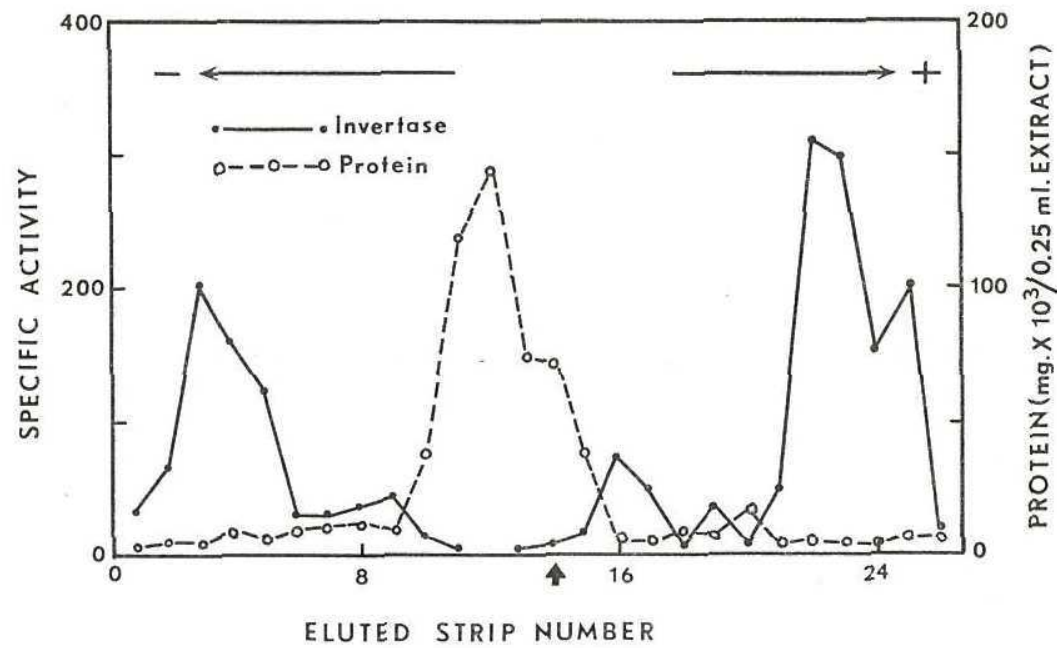

FIG. 3.-Separation of invertase from inert protein by paper electrophoresis. Paper strips were cut into $1-\mathrm{cm}$. sections and eluted with $1 \mathrm{ml}$. of water. Arrow indicates point of sample application.

peaks. Initial electrophoresis runs of 6 to 8 hours gave good protein distribution, but failed to show any sign of invertase. It was soon learned that two invertases rapidly separate from the protein and within 6 hours will have passed completely off the paper. Figure 3 illustrates a typical 3-hour run in 
which the mass of protein has just begun to move toward the negative electrode, while invertase activity has already appeared toward either end of the paper strip. It is interesting to note that both positively and negatively charged invertase was present in the single invertase peak derived from Sephadex. The invertases of sugarcane certainly seem to be complex, having already shown differences on the basis of substrate specificity (1), $\mathrm{pH}$ and $\mathrm{Km}$ (Michaelis constant) values $(1,13,15,17)$, and molecular size $(17)$.

The migration of meristem protein toward the negative electrode was not anticipated. Earlier electrophoresis studies with leaf amylases revealed

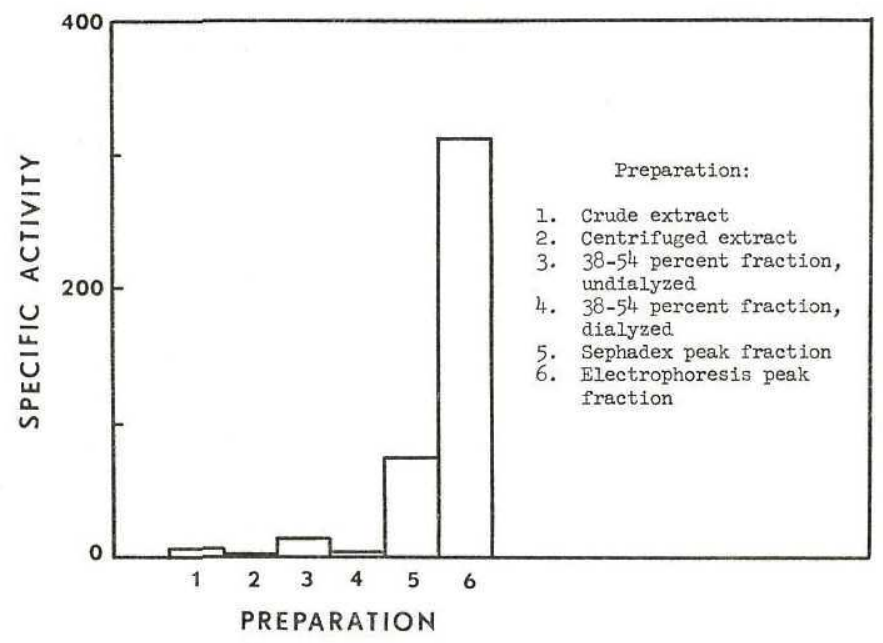

FIG. 4.-Specific-activity values for sugarcane invertase during progressive stages of purification.

a rapid protein migration toward the positive pole. The positively charged protein of the present studies corresponds closely to the amylase movement observed during the previous work.

Separation of invertase from other protein made possible the first really high specific-activity values we have gained without use of activators. Figure 4 summarizes the progressive purification steps followed during the present study.

\section{SUMMARY}

A fair degree of sugarcane invertase purification has been achieved by techniques of differential solubility, gel filtration, and paper electrophoresis. Invertase is readily salted out with ammoniun sulfate between 38- and 52percent saturation. Activity is largely lost during dialysis against distilled 
water, but is regained by passage through columns of G-200 Sephadex gel. Reactivation is attributed to removal of unknown inhibitors. Filtration did not accomplish good separation of invertase from other protein.

Electrophoresis experiments showed that invertases are quite mobile compared to contaminant protein, and move quickly toward positive and negative electrodes. Two distinct invertase areas were obtained free of contaminant protein, one enzyme bearing a positive charge and the other a negative charge. Filtration and electrophoresis steps described herein achieved good enzyme purification without use of glucose or manganese, and thus avoided the appearance of reconstituted invertase.

\section{RESUMEN}

Mediante las técnicas de solubilidad diferencial, filtración de gel y la electrofóresis de papel se ha obtenido un buen grado de purificación de la invertasa de la caña de azúcar. La invertasa puede separarse rápidamente con sales de sulfato amónico a una saturación de un 38 a un 52 por ciento. La actividad desaparece casi totalmente durante la diálisis can agua destilada, pero se restablece pasándola a través de columnas de gel Sephadex G-200. Se atribuye la reactivación a la remoción de inhibidores desconocidos. No fue posible separar bien la invertasa de otras proteínas mediante la filtración.

Las pruebas de electrofóresis demostraron que las invertasas son bastante móviles comparadas con las proteínas contaminadoras, y se mueven con rapidez hacia los electrodos positivo y negativo. Se obtuvieron dos distintas áreas de invertasa libres de proteína contaminadora, una de las cuales se comprobó tener una carga positiva y otra una carga negativa. Los procesos de filtración y electrofóresis, ya descritos, permitieron una buena purificación de las enzimas, sin que fuera necesario usar glucosa o manganeso, evitando así la aparición de la invertasa reconstituída.

\section{LITERATURE CITED}

1. Alexander, A. G., Hydrolytic proteins of sugarcane: The acid invertases, $J$. Agr. Univ. P.R. $49(3): 287-307,1965$.

2. - Invertases of sugarcane, Proc. IX Cong. Latin Amer. Chem. Soc., San Juan, P.R., 1965 (in press).

3. - Effects of tungsten and molybdenum on sucrose content and hydrolytic enzymes of immature sugarcane, J. Agr. Univ. P.R. 49(4): 429-42, 1965.

4. - Behavior of enzymes governing starch- and sucrose-forming pathways in two sugarcane varieties supplied with variable nitrate and phosphate in sand culture, J. Agr. Univ. P.R. 49(2): 153-75, 1965.

5. - - Effects of amylase and invertase regulators upon sugar content, protein content, and enzyme activity of immature sugarcane, J. Agr. Univ. P.R.50(1): 18-35, 1966.

6. - Evaluation of sucrose-enzyme relationships among 12 P.R. sugarcane varieties, J. Agr. Univ. P.R. 51(1): 4-21, 1967. 
7. —- Enzyme-sugar relationships in immature sugarcane treated with ascorbic acid, cysteine, hydroxylamine, cyanide, silicon, and iron, J. Agr. Univ. P.R. 51 (1): 46-54, 1967.

8. - - Gel filtration studies of sugarcane phosphatases, J. Agr. Univ. P.R. 50(4): 293-302, 1966.

9. Alexander, A. G., and Lebrón, J., Isolation and purification of sugarcane leaf amylases, Plant Physiol. (Submitted for publication).

10. Flodin, P., and Aspberg, K., Biological Structure and Function, Academic Press, New York, N.Y. 1: 345-49, 1961.

11. Gelotte, B., and Krantz, H. B., Acta Chem. Scand. 18: 2127, 1959.

12. Glasziou, K. T., Accumulation and translocation of sugars in stalks of sugarcane. Origin of glucose and fructose in the inner space, Plant Physiol. 36(2): 175-9, 1961.

13. Glasziou, K. T., Hatch, M. D., and Sacher, J. A., Accumulation and translocation of sugars in sugarcane storage tissue, Proc. 11th Cong. I. S. S. C. T., Mauritius, pp. 334-338, 1962.

14. Granath, K. A., and Flodin, P., Makromol, Chem. 48: 160, 1961.

15. Hatch, M. D., Sacher, I. A., and Glasziou, K. T., Sugar accumulation cycle in sugarcane. I. Studies on enzymes of the cycle, Plant Physiol. 38(3): 338-43, 1963.

16. Hatch, M. D., and Glasziou, K. T., Sugar accumulation cycle in sugarcane: II, Relationships of invertase activity to sugar content and growth rate in storage tissue of plants grown in controlled environments, Plant Physiol. 38(3): 344-48, 1963.

17. Maretsky, A., and Alexander, A. G., Gel filtration studies of invertase from sugarcane meristem, Enzymologia (submitted for publication).

18. Sacher, J. A., and Glasziou, K. T., Regulation of invertase levels in sugarcane by an auxin-carbohydrate mediated control system, Biochem. \& Biophys. Research Comm. 8(4): 281-2, 1962.

19. Sacher, J. A., Hatch, M. D., and Glasziou, K. T., Regulation of invertase synthesis in sugarcane by an auxin- and sugar-mediated control system, Physiol. Plantarum 16: 836-42, 1963.

20. Samuels, G., and Alexander, A. G., Influence of variable manganese and silicon on the nutrition, sugar production, and enzyme activity of immature sugarcane, Plant Physiol. (submitted for publication).

21. Sumner, J. B., Dinitrosalicylic acid: A reagent for the estimation of sugar in normal and diabetic urine, J. Biol. Chem. 47: 5-9, 1921.

22. Sutherland, E. W., Cori, C. F., Haynes, R., and Olsen, N. S., Purification of the hyperglycemic-glycogenolytic factor from insulin and from gastric mucosa, J. Biol. Chem. 180: 825-37, 1949. 